Reqyrizendri, D., Prihartanti, N., \& Asyanti, S. (2020). Smoking among muslim students behaviour case study in Surakarta. Indigenous: Jurnal Ilmiah Psikologi, 5(2). 218-230. doi: https:// doi.org/10.23917/indigenous.v5i2.10998

\title{
Smoking Among Muslim Students \\ Behavior Case Study in Surakarta
}

\author{
Dyotisaddha Reqyrizendri ${ }^{1}$, Nanik Prihartanti ${ }^{2}$, Setia Asyanti ${ }^{3}$
}

Fakultas Psikologi, Universitas Muhammadiyah Surakarta ${ }^{1,2,3}$

dyotisaddha@gmail.com ${ }^{1}$, nanik_prihartanti@ums.ac.id ${ }^{2}$, setia.asyanti@ums.ac.id ${ }^{3}$

\begin{tabular}{|l|l|l}
\hline Submitted: 31 May 2020 & Accepted: 27 November 2020 & Published: 30 November 2020
\end{tabular}

\begin{abstract}
Based on various studies, cigarettes are harmful to the health of both active and passive smokers. That is the reason The Fatwa and Islamic Research Council, The Central Board of Muhammadiyah forbidding smoking behavior (haram). Nevertheless, many muslim students at University smoke. The purpose of this study is to descibe smoking behavior of Muslim students in Surakarta. The informants are active smokers $(n=119)$ determined by purposive sampling. This study uses qualitative research methods with an exploration approach. The result shows that the students initiate their smoking behavior since junior high school. The internal factors that affect smoking behavior are the need for pleasure, existence, acceptance of social environment and stress coping. The external factors consist of social and family environment that have smoking habit. Smoking behavior continues because students tend to consider short-term benefits (psychological and social) rather than the long term health risks. The active smoker students do not identify themselves as part of the Muhammadiyah community therefore they do not concern about the Fatwa issued by The Central Board of Muhammadiyah. Most students want to quit smoking for two reasons: the encouragement of the closest people who object to smoking behavior and feeling a deterioration in health.
\end{abstract}

Keywords: muslim; smoking behavior; university student

\section{INTRODUCTION}

Smoking has become a common habit in Indonesia, even as if it has become a culture. Deputy for Child Development at the Ministry of Women's Empowerment and Child Protection stated that the number of smokers in Indonesia is almost 90 million people, and currently, Indonesia is in the first rank of most smokers in the world (Putri, 2017). It is of course highly concerning considering that smoking can endanger health.

Smoking behavior, seen from various points of view, is highly detrimental to both oneself and those around them. According to Kaplan (Komasari \& Helmi, 2011), for active smokers, smoking stimulates cancer and various other diseases such as narrowing of blood vessels, high blood pressure, heart disease, lung disease, and chronic bronchitis. Smoking also has negative effects on passive smokers. However, the smoking habit is still widely practiced in society (Ambarwati et al., 2014). It is because there is no law that regulates smoking prohibition. If any, these rules are only minor restrictions that only apply in certain places. There is no strict prohibition from the government due to the importance of tobacco companies to the country. Based on Customs and 
Excise data from the Ministry of Finance, 90 percent of excise revenue comes from the Tobacco Products Industry (kompas.com, 2018).

Cigarette companies spend massively on promoting their products. The main target of tobacco company promotion is not adults but young people. According to (Salim, 2013), all tobacco industry marketing activities are a systematic series aimed at recruiting children to become novice smokers. Cigarette advertising materials that associate smoking with cool, manly, confident, and masculine images clearly show that the target market segmentation is children and adolescents. They are exposed to cigarette advertisements wherever they are. Hence, it is not surprising that smoking behavior often begins when someone in their teen's ages. Smet (1994) explained that the initial age of smoking generally ranged from 11-13 years old and they generally smoke before the age of 18 years.

Students as intellectuals are expected to have a high sensitivity to social phenomena that occur in society (Trisnowati et al., 2017). Students having a role as agents of change and social controllers should have the moral strength and become an example for the general public (Muliyana \& M.Thaha, 2013). It is not in line with the reality on the ground. A survey conducted on medical students at Addis Ababa University reported a current smoking prevalence of $1.8 \%$. A survey conducted among college students in southwest Nigeria showed that the prevalence of college students who have ever smoked is $22.0 \%$, while the current smoking prevalence is $13.7 \%$. Likewise, a study conducted among college students in Cameroon reported a student prevalence of having smoked is $30.1 \%$ and a current smoking prevalence is $6.3 \%$ (Hossain et al., 2017). A survey that was conducted at Hasanuddin University showed that $49 \%$ of students smoke (Muliyana \& M.Thaha, 2013). Basic Health Research data in 2013 indicated that $27.2 \%$ of Indonesian citizens aged 20-24 years, which is the age range for students, are active smokers (Meilani \& Marnally, 2017).

Next, preliminary data collection was performed to determine how smoking behavior among students of private universities in Surakarta. Researchers distributed questionnaires to 23 private university students with an age range of 19-25 years from different departments on December 19-20, 2018, and January 8, 2019. Based on the classification of smoking behavior by (Smet, 1994), the questionnaire results indicated that $8.7 \%$ are light smokers (1-4 cigarettes/day), $65.2 \%$ are moderate smokers (5-14 cigarettes/day), and $26.1 \%$ are heavy smokers ( $\geq 15$ cigarettes/ day).

Furthermore, smoking behavior in Indonesia is revealed to be inversely proportional to the income of cigarette consumers (Sugiharti et al., 2015). The results of research by (Krishna et al., 2010) showed that students at the Universitas Pendidikan Indonesia have a moderate level of financial literacy $(63 \%)$, and only $7 \%$ have a high level of financial literacy, while the rest $(30 \%)$ belong to the group that has a low level of financial literacy. It indicated that cigarette consumption by students has a negative impact on their economic level. Based on the results of a study from the Nutrition \& Health Surveillance System 1998 - 2000 (in (Sugiharti et al., 2015), it was generally concluded that smoking can worsen poverty levels because limited family income is prioritized for spending on tobacco and tobacco products.

The above field data also contradicts Muhammadiyah's policy that prohibits smoking. On March 8, 2010, the Tarjih and Tajdid Council of Muhammadiyah Central Leadership issued a Fatwa stating that smoking is haram because smoking is an act that endangers oneself and others. Thus, it is against Islamic sharia. Moreover, it is also explained that those who have not or do not smoke are obliged to avoid themselves and their families from smoking trials, while those who have already become smokers are required to make efforts and try according to their ability to quit 
smoking (Abdulla, 2020).

Based on the statement above, the researcher conducted a study that aims to describe the smoking behavior of Muslim college students in Surakarta. To achieve this goal, the researcher asked several research questions, including the initiation of smoking behavior in students, the factors that influence them to smoke, the reasons why students keep this behavior, their behavior towards Muhammadiyah's fatwa regarding smoking, and the strategies needed to reduce smoking intensity. Hence in the future, this research can be used as an additional reference for researchers in the field of health psychology, especially research that discusses smoking behavior in college students. Besides that, it is also a reference material to explain the dynamics of smoking behavior in students.

\section{METHOD}

This study used a qualitative research method with an exploratory approach to explore more about smoking behavior among college students. The number of informants in this study was 119 Muslim students, who were a sample of 12 faculties in private universities. Determination of informants was through purposive sampling with the following criteria (a) students of the Universitas Muhammadiyah Surakarta; (b) male; (c) active smoker. To test the validity of the data, especially on the credibility of the research, this study implemented peer-reviewing. Peer reviewing was conducted by discussing with supervisor 1 and supervisor 2. Permission in this research was the willingness of the subject to become research informants by filling in the informed consent.

Data collection in this study utilized an open questionnaire with the following question aspects: (a) initiation of smoking behavior (with sample questions: I have been smoking since ..., etc.); (b) the factors that influence smoking behavior (with examples of questions: What attracted me to smoking for the first time was ..., etc.); (c) reasons for keeping smoking behavior (with examples of questions: I maintain smoking behavior because ..., etc.); (d) behavior towards Muhammadiyah's Fatwa regarding smoking (with an example of a question: In my opinion smoking based on the law is ..., etc.); and (e) the strategies needed to quit smoking (with an example question: The efforts I have made to quit smoking are ..., etc.).

The smoking intensity classification refers to Smet (1994) where there are three types of smokers classified according to the number of cigarettes smoked, namely: (a) heavy smokers who smoke more than 15 cigarettes a day; (b) moderate smokers who smoke 5-14 cigarettes a day; (c) light smokers who smoke 1-4 cigarettes a day. The results of the questionnaire were then analyzed by referring to five stages (Krishna et al., 2007), namely organizing data; reading and marking data; describing, classifying and interpreting data into codes and themes; interpreting the whole data; and restating and displaying data from the analysis results.

\section{RESULTS AND DISCUSSION}

Informants' initiation of smoking behavior mostly started when they were at the junior high school level (35.29\%) and most were introduced by their schoolmate (58.82\%). Most of the informants also lived in the boarding house where the informants lived with their friends (59.66\%). These results certainly strengthen the smoking behavior of the informants so that they became active smokers. Most of the informants are included in the category of light smokers $(43.70 \%)$ and moderate (43.70\%). Furthermore, it can be seen in Table 1. 
Table 1.

Initiation of Informant's Smoking Behavior

\begin{tabular}{llll}
\hline \multicolumn{2}{c}{ Initiation of the Informant's Smoking Behavior } & Total & Percentage \\
\hline Educational background for & Elementary School & 18 & $15,13 \%$ \\
the first time of smoking & Junior High School & 42 & $35,29 \%$ \\
& Senior High School & 37 & $31,09 \%$ \\
& Graduated from high school & 22 & $18,49 \%$ \\
\hline Source of Cigarette & Parents/family & 16 & $13,45 \%$ \\
Introduction & Schoolmate & 70 & $58,82 \%$ \\
& Friends outside of school & 20 & $16,81 \%$ \\
& Advertisement & 4 & $3,36 \%$ \\
& Other & 9 & $7,56 \%$ \\
\hline Smoking Intensity (per day) & Light (1-4 cigarettes) & 52 & $43,70 \%$ \\
& Moderate (5-14 cigarettes) & 52 & $43,70 \%$ \\
& Heavy ( $\geq 15$ cigarettes) & 15 & $12,61 \%$ \\
\hline
\end{tabular}

Informants with moderate intensity have mostly smoked since junior high school. Informants with light intensity mostly smoked since they were at the high school education level (Table 2).

Table 2.

Cross Tabulation of Intensity and Initiation of Smoking in Informants

\begin{tabular}{|c|c|c|c|c|c|c|c|c|}
\hline \multicolumn{9}{|c|}{ Initiation of Smoking } \\
\hline \multirow{2}{*}{ Intensity } & \multicolumn{2}{|c|}{$\begin{array}{l}\text { Elementary } \\
\text { School }\end{array}$} & \multicolumn{2}{|c|}{$\begin{array}{l}\text { Junior High } \\
\text { School }\end{array}$} & \multicolumn{2}{|c|}{$\begin{array}{l}\text { Senior High } \\
\text { School }\end{array}$} & \multicolumn{2}{|c|}{$\begin{array}{l}\text { Graduate From } \\
\text { High School }\end{array}$} \\
\hline & $\sum$ & $\%$ & $\sum$ & $\%$ & $\sum$ & $\%$ & $\sum$ & $\%$ \\
\hline Light & 4 & $3,36 \%$ & 16 & $13,45 \%$ & 17 & $14,29 \%$ & 15 & $12,61 \%$ \\
\hline Moderate & 10 & $8,40 \%$ & 21 & $17,65 \%$ & 15 & $12,61 \%$ & 6 & $5,04 \%$ \\
\hline Heavy & 4 & $3,36 \%$ & 5 & $4,20 \%$ & 5 & $4,20 \%$ & 1 & $0,84 \%$ \\
\hline
\end{tabular}

The factors that influenced informants to try cigarettes are mostly internal (80.67\%). These internal factors included curiosity, the informant's desire to be accepted in the social environment, the desire to be seen as a cool person, and the desire to obtain pleasure from smoking. After the informants tried smoking for the first time, most of them had negative experiences $(52.10 \%)$ such as bitter taste, coughing, shortness of breath, dizziness, and others. The negative experiences felt by the informants did not stop their smoking behavior. The informants actually continued this behavior. It is because the informants wanted to enjoy smoking like other friends or family members who also smoke $(41.18 \%)$. This smoking behavior was also supported by the number of active smokers in the informants' social environment $(58.82 \%)$ so that the informants decided to become active smokers. Furthermore, because they were accustomed to smoking, the informants began to feel the sensations when smoking both physically $(25.21 \%)$, thoughts $(21.85 \%)$, and feelings $(21.85 \%)$. These sensations included feeling refreshed and comfortable in the body, calming the mind, feeling happy, relaxed, and relieved.

The positive sensation felt by informants generated them smoke in various places (57.98\%), namely in boarding houses, gathering places (hanging out), houses, and even on campus. Informants also smoked at every opportunity (61.34\%), i.e., when hanging out with friends, when there are many 
thoughts or problems, when not doing any activities, after eating, when defecating, and others. The rest of the data can be seen in Table 3 .

Table 3.

Factors Affecting Smoking Behavior

\begin{tabular}{|c|c|c|c|}
\hline & Factors Affecting Smoking Behavior & Total & Percentage \\
\hline \multirow{3}{*}{$\begin{array}{l}\text { Factors Affecting Informants } \\
\text { Trying to Smoke }\end{array}$} & internal factors & 96 & $80,67 \%$ \\
\hline & external factors & 12 & $10,08 \%$ \\
\hline & others & 11 & $9,24 \%$ \\
\hline \multirow{3}{*}{$\begin{array}{l}\text { First Experience of Trying to } \\
\text { Smoke }\end{array}$} & positive experience & 40 & $33,61 \%$ \\
\hline & negative experience & 62 & $52,10 \%$ \\
\hline & just normal & 17 & $14,29 \%$ \\
\hline \multirow{6}{*}{$\begin{array}{l}\text { Factors Affecting Informants } \\
\text { Deciding to Become Smokers }\end{array}$} & the need for pleasure & 49 & $41,18 \%$ \\
\hline & the need for the existence & 9 & $7,56 \%$ \\
\hline & the need to be accepted & 10 & $8,40 \%$ \\
\hline & coping with stress & 20 & $16,81 \%$ \\
\hline & others & 15 & $12,61 \%$ \\
\hline & combination & 16 & $13,45 \%$ \\
\hline \multirow[t]{4}{*}{ Smokers around Informants } & family environment & 7 & $5,88 \%$ \\
\hline & social environment & 70 & $58,82 \%$ \\
\hline & general public & 6 & $5,04 \%$ \\
\hline & all environment & 36 & $30,25 \%$ \\
\hline \multirow[t]{6}{*}{ The sensation felt when smoking } & physical & 30 & $25,21 \%$ \\
\hline & mind & 26 & $21,85 \%$ \\
\hline & feeling & 26 & $21,85 \%$ \\
\hline & just normal & 10 & $8,40 \%$ \\
\hline & combination & 16 & $13,45 \%$ \\
\hline & others & 11 & $9,24 \%$ \\
\hline \multirow{5}{*}{$\begin{array}{l}\text { Where the informants used to } \\
\text { smoke }\end{array}$} & house & 7 & $5,88 \%$ \\
\hline & boarding house & 26 & $21,85 \%$ \\
\hline & campus & 8 & $6,72 \%$ \\
\hline & others & 9 & $7,56 \%$ \\
\hline & combination & 69 & $57,98 \%$ \\
\hline \multirow[t]{5}{*}{ Informants' Smoking Time } & gather (hang out) with friends & 22 & $18,49 \%$ \\
\hline & lots of thoughts/problems & 7 & $5,88 \%$ \\
\hline & not doing any activities & 12 & $10,08 \%$ \\
\hline & others & 5 & $4,20 \%$ \\
\hline & combination & 73 & $61,34 \%$ \\
\hline
\end{tabular}

Most of the informants knew about the dangers of smoking, especially physically (63.03\%). The physical dangers mentioned by the informants are the long-term dangers of smoking, for example, cancer, heart disease, respiratory problems, and others. Regardless of the dangers of smoking they knew, for informants, there were numerous benefits obtained directly from smoking, especially psychological benefits (53.78\%). These benefits included reducing stress, reducing anxiety, increasing concentration, creativity, and self-confidence. Another advantage was that it can 
strengthen friendships and break the ice when chatting with friends. These direct benefits make the informants kept their smoking behavior, even though when they did not smoke, most informants felt normal or did not feel any complaints (33.61\%). The rest of the data can be seen in Table 4 .

Table 4.

Reasons for Maintaining Smoking Behavior

\begin{tabular}{|c|c|c|c|}
\hline \multicolumn{2}{|c|}{ Reasons to Keep Smoking Behavior } & Total & Percentage \\
\hline \multirow{6}{*}{$\begin{array}{l}\text { Informant Knowledge About the } \\
\text { Dangers of Smoking }\end{array}$} & physical harm & 75 & $63,03 \%$ \\
\hline & mental harm & 2 & $1,68 \%$ \\
\hline & harm to others & 2 & $1,68 \%$ \\
\hline & harm to financial & 14 & $11,76 \%$ \\
\hline & combination & 21 & $17,65 \%$ \\
\hline & not harmful & 5 & $4,20 \%$ \\
\hline \multirow[t]{6}{*}{ Benefits of Smoking for Informants } & physical benefits & 6 & $5,04 \%$ \\
\hline & psychological benefits & 64 & $53,78 \%$ \\
\hline & social benefits & 14 & $11,76 \%$ \\
\hline & other & 11 & $9,24 \%$ \\
\hline & combination & 11 & $9,24 \%$ \\
\hline & no benefits & 13 & $10,92 \%$ \\
\hline \multirow{5}{*}{$\begin{array}{l}\text { Complaints of Informants when Not } \\
\text { Smoking }\end{array}$} & physical complaints & 25 & $21,01 \%$ \\
\hline & psychological complaints & 35 & $29,41 \%$ \\
\hline & physical and psychological complaints & 12 & $10,08 \%$ \\
\hline & positive & 7 & $5,88 \%$ \\
\hline & just normal & 40 & $33,61 \%$ \\
\hline
\end{tabular}

Regarding the Fatwa issued by the Tarjih and Tajdid Council of Muhammadiyah Central Leadership that stated that smoking is haram, most informants knew this $(63.03 \%)$ but chose to be indifferent (44.54\%). It is because the informants considered the fatwa only binding on those who belonged to the Muhammadiyah organization, while the informants felt they are not part of the Muhammadiyah organization. They had their own opinion regarding smoking behavior law. Most of the informants thought that smoking is makruh (46.22\%). It means an act that should not be done, but if it is still done, it does not obtain sin. According to them, smoking had more disadvantages than benefits. Most of the informants, who saw Muhammadiyah's Fatwa on smoking behavior, argued that smoking is makruh. Meanwhile, most of the informants who were not aware of the Fatwa had the opinion that smoking is halal or lawful. Regarding the ban, some informants insisted that they will still smoke (47.06\%), and some others confirmed that they will quit smoking (52.94\%). Most of the informants who had the opinion that the smoking law is makruh will stop smoking if smoking is prohibited. Meanwhile, most of the informants, who had the opinion that smoking is halal, said that they will continue to smoke even though smoking is prohibited. The reason the informants continued to smoke was that according to them, smoking is their right and it does not harm other people (46.43\%). Another reason was that the prohibition is less strict. If smoking is indeed prohibited, cigarettes should not be sold in various places. The informant has experienced addiction, so it will be difficult not to smoke if the prohibition is not firm. Meanwhile, the informants' reason chose to quit smoking was because it is a religious rule and prohibition that must be obeyed even if forced. Another reason is that the informants wanted to live a healthy life 
and had the intention to quit smoking beforehand.

Most of the informants who kept their smoking behavior for psychological reasons are found not to feel any effects or feel normal when they did not smoke (Table 5).

Table 5.

Cross-tabulation of Reasons to Keep Smoking and Effects when Not Smoking

\begin{tabular}{|c|c|c|c|c|c|c|c|c|c|c|}
\hline \multicolumn{11}{|c|}{ Effects of not smoking } \\
\hline \multirow[t]{2}{*}{$\begin{array}{c}\text { Reasons to } \\
\text { keep smoking }\end{array}$} & \multicolumn{2}{|c|}{$\begin{array}{c}\text { Physical } \\
\text { complaints }\end{array}$} & \multicolumn{2}{|c|}{$\begin{array}{l}\text { Psychological } \\
\text { complaints }\end{array}$} & \multicolumn{2}{|c|}{$\begin{array}{c}\text { Physical \& } \\
\text { psychological } \\
\text { complaints }\end{array}$} & \multicolumn{2}{|c|}{ Positive effect } & \multicolumn{2}{|c|}{ Just normal } \\
\hline & $\sum$ & $\%$ & $\sum$ & $\%$ & $\sum$ & $\%$ & $\sum$ & $\%$ & $\sum$ & $\%$ \\
\hline $\begin{array}{l}\text { Physical } \\
\text { reasons }\end{array}$ & 3 & $2,52 \%$ & 1 & $0,84 \%$ & 0 & $0,00 \%$ & 0 & $0,00 \%$ & 1 & $0,84 \%$ \\
\hline $\begin{array}{l}\text { Psychological } \\
\text { reasons }\end{array}$ & 16 & $13,45 \%$ & 21 & $17,65 \%$ & 4 & $3,36 \%$ & 0 & $0,00 \%$ & 26 & $21,85 \%$ \\
\hline Social reasons & 1 & $0,84 \%$ & 1 & $0,84 \%$ & 0 & $0,00 \%$ & 1 & $0,84 \%$ & 1 & $0,84 \%$ \\
\hline Others & 0 & $0,00 \%$ & 5 & $4,20 \%$ & 2 & $1,68 \%$ & 4 & $3,36 \%$ & 5 & $4,20 \%$ \\
\hline Combination & 5 & $4,20 \%$ & 7 & $5,88 \%$ & 6 & $5,04 \%$ & 2 & $1,68 \%$ & 7 & $5,88 \%$ \\
\hline
\end{tabular}

Table 6.

Behavior toward Smoking Fatwa

\begin{tabular}{|c|c|c|c|}
\hline \multicolumn{2}{|l|}{ Behavior toward Smoking Fatwa } & \multirow{2}{*}{$\frac{\text { Total }}{75}$} & \multirow{2}{*}{$\frac{\text { Percentage }}{63,03 \%}$} \\
\hline Informants' Knowledge about Muhammadiyah Fatwa on & know & & \\
\hline Smoking & do not know & 44 & $36,97 \%$ \\
\hline \multirow{4}{*}{$\begin{array}{l}\text { Behavior of Informants regarding Muhammadiyah Fatwa on } \\
\text { Smoking }\end{array}$} & agree & 34 & $28,57 \%$ \\
\hline & against & 22 & $18,49 \%$ \\
\hline & indifferent & 53 & $44,54 \%$ \\
\hline & confused & 10 & $8,40 \%$ \\
\hline \multirow[t]{4}{*}{ Opinion of Informants Regarding the Law of Smoking } & halal & 32 & $26,89 \%$ \\
\hline & mubah & 18 & $15,13 \%$ \\
\hline & makruh & 55 & $46,22 \%$ \\
\hline & haram & 14 & $11,76 \%$ \\
\hline \multirow{2}{*}{$\begin{array}{l}\text { Continuation of Smoking Behavior if Smoking is prohibited } \\
\text { by religion }\end{array}$} & keep smoking & 56 & $47,06 \%$ \\
\hline & quit smoking & 63 & $52,94 \%$ \\
\hline
\end{tabular}

Apart from the Muhammadiyah Fatwa, most informants (Figure 1) actually have a desire to quit smoking $(69.75 \%)$. It is because they were aware of the dangers of smoking and wanted to live a healthy life. Informants began to feel the negative effects of smoking on their bodies. Another reason is because of the encouragement from family, religion prohibits, and economic reasons.

Efforts that have been made by the informants to quit smoking are by reducing smoking intensity $(65.06 \%)$ or replacing cigarettes with snacks, motivating themselves, and diverting the desire to smoke with other things (Figure 2). However, these efforts often failed due to the informants' social environment, who generally were also smokers, lack of motivation, and psychological problems. The difficulties experienced by the informants when trying to quit smoking included dealing with the smoker's environment, when facing psychological problems such as when experiencing stress and anxiety, when there is no activity, and a sense of dependence on cigarettes. 


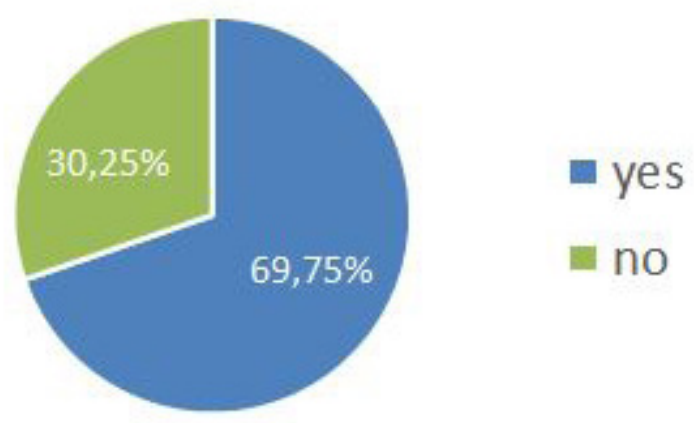

Figure 1.

Desire to Quit Smoking

Efforts that have been made by the informants to quit smoking are by reducing smoking intensity $(65.06 \%)$ or replacing cigarettes with snacks, motivating themselves, and diverting the desire to smoke with other things (Figure 2). However, these efforts often failed due to the informants' social environment, who generally were also smokers, lack of motivation, and psychological problems. The difficulties experienced by the informants when trying to quit smoking included dealing with the smoker's environment, when facing psychological problems such as when experiencing stress and anxiety, when there is no activity, and a sense of dependence on cigarettes.

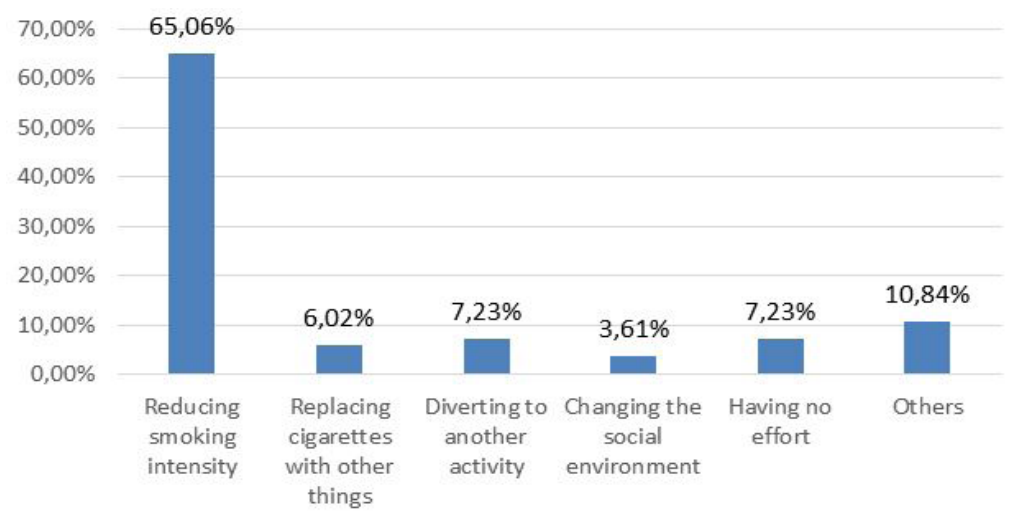

Figure 2.

Efforts that have been made to quit smoking

According to the informants, an effective strategy to stop smoking was an internal strategy (44.54\%), including determining to quit smoking, reducing intensity, diverting by doing positive activities, staying away from the smoker's environment, replacing cigarettes with candy or other snacks, and following psychological therapy. External strategies $(31.93 \%)$ included changing the environment by avoiding smoking, substitution (changing to candy or snacks), and psychological therapy. Meanwhile, other strategies included the government eliminating cigarettes, closing cigarette factories, increasing cigarette prices, and providing fines for smokers.

Informants' initiation of smoking behavior mostly started when they were at the junior high school level of education (35.29\%), namely the age of 12-15 years, and most were introduced by their schoolmate $(58.82 \%)$. Most of the informants lived in the boarding house where the informants lived with their friends (59.66\%). It certainly strengthens the smoking behavior of the informants so that they become active smokers. Smet (Komasari \& Helmi, 2011) said that the age at first smoking generally ranged from 11-13 years old and they generally smoked before the age of 18 
years. The smoking behavior for students began due to lack of information and misunderstanding of information, being consumed by advertisements, or being persuaded by friends (Nurmiyanto \& Rahmani, 2013). Peer influence is a significant factor in smoking behavior in adolescents. The closer their friendship, the more they influence each other (Lloyd et al., 1998).

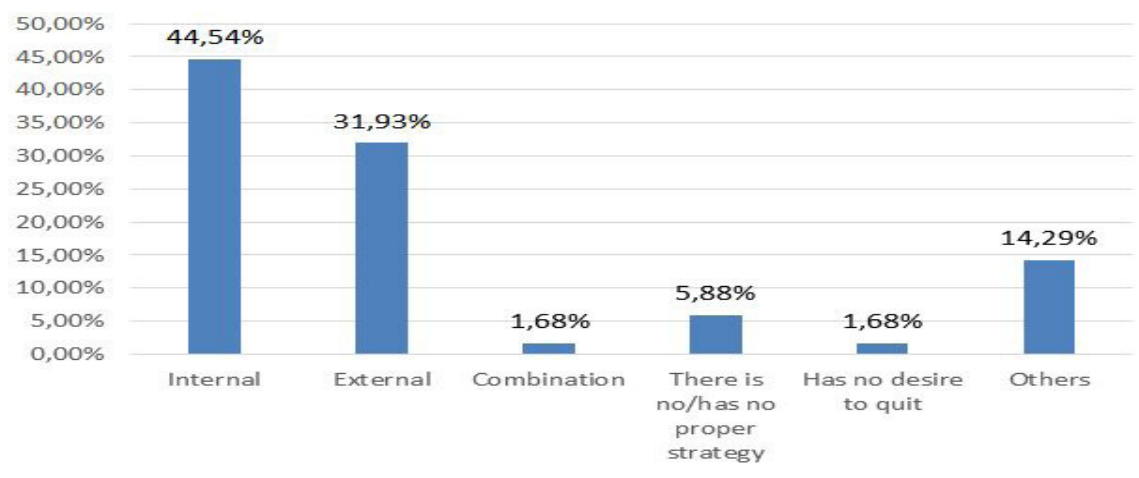

Figure 3.

Strategies for Quitting Smoking Behavior

The factors that influenced informants to try cigarettes are mostly internal (80.67\%). These internal factors included curiosity, the informant's desire to be accepted in the social environment, the desire to be seen as a cool person, and the desire to obtain pleasure from smoking. After the informants tried smoking for the first time, most of them had negative experiences $(52.10 \%)$ such as bitter taste, coughing, shortness of breath, dizziness, and others. However, it did not stop their smoking behavior. The informants actually continued this behavior. It is because the informants wanted to enjoy smoking like other friends or family members who also smoked (41.18\%). This smoking behavior was also supported by the number of active smokers in the social environment (58.82\%) of the informants so that the informants decided to become active smokers. It is in line with the theory according to Levethal and Cleary (Oskamp, 1984), which explained that there are factors that influence smoking behavior. Some of them are positive emotional reactions. Smoking is used to produce positive emotions, such as pleasure, relaxation, and enjoyment of taste. Smoking can also show pride or show maturity. Social reasons are also one of the other factors that influence smoking behavior. Smoking is intended to follow group habits (generally adolescents and children), identify with other smokers, and determine a person's self-image.

Furthermore, because they are accustomed to smoking, the informants began to feel the sensations when smoking both physically $(25.21 \%)$, thoughts $(21.85 \%)$, and feelings $(21.85 \%)$. These sensations included feeling refreshed and comfortable in the body, calming the mind, feeling happy, relaxed, and relieved. The positive experiences felt by the informants made them smoke in various places (57.98\%), namely in boarding houses, gathering places (hanging out), houses, and even at the campus. Informants also smoked at every opportunity (61.34\%), including when hanging out with friends, when there are many thoughts or problems, when not doing any activities, after eating, when defecating, and others. A smoker smokes because it helps him regulate mood and reduce the negative impact when faced with stress (Slopen et al., 2013). Moreover, smoking behavior can provide satisfaction for young people, regardless of its pharmacological effects and stress reduction. Smoking behavior has been called an attempt to fill spare time, pass time, prevent boredom, and complete the day or activity. Holding cigarette packs, matches, lighting cigarettes, inhaling, exhaling, seeing cigarette smoke drifting away, and blowing cigarette smoke are identified 
to provide pleasure/pleasure for young and adult smokers (Lloyd et al., 1998). A summary of the research results can be observed in Table 7 .

Table 7.

Summary of Research Results

\begin{tabular}{|c|c|c|}
\hline & Indicators & Conclusion \\
\hline \multirow{3}{*}{$\begin{array}{l}\text { Initiation of } \\
\text { Smoking }\end{array}$} & Initiation of Smoking & Junior High School \\
\hline & Source of Initiation & Schoolmate \\
\hline & Smoking intensity & Light and moderate smokers \\
\hline \multirow{7}{*}{$\begin{array}{l}\text { Factors Affecting } \\
\text { Smoking } \\
\text { Behavior }\end{array}$} & Factor trying to smoke for the first time & Curiosity \\
\hline & Experience trying to smoke for the first time & $\begin{array}{l}\text { Negative experiences (bitter taste, coughing, } \\
\text { shortness of breath, dizziness) }\end{array}$ \\
\hline & Factor deciding to become a smoker & $\begin{array}{l}\text { The need for enjoyment, existence, acceptance, } \\
\text { coping strategies }\end{array}$ \\
\hline & Smokers around informants & Social environment \\
\hline & The sensation informants feel when smoking & $\begin{array}{l}\text { Feeling refreshed and comfortable, calming } \\
\text { mind, feeling happy, serene and relieved }\end{array}$ \\
\hline & Where the informant used to smoke & Various places \\
\hline & When the informant used to smoke & Any time \\
\hline \multirow{4}{*}{$\begin{array}{l}\text { Reasons to } \\
\text { Keep Smoking } \\
\text { Behavior }\end{array}$} & Reasons for keeping smoking behavior & $\begin{array}{l}\text { Psychological reasons (calming the mind, } \\
\text { improving concentration, decreasing anxiety) }\end{array}$ \\
\hline & Knowledge about the dangers of smoking & Long term physical harm \\
\hline & Benefits of smoking for informants & $\begin{array}{l}\text { Direct benefits (reducing stress, reducing } \\
\text { anxiety, increasing concentration, creativity, } \\
\text { and self-confidence) }\end{array}$ \\
\hline & Complaints when not smoking & Just normal \\
\hline \multirow{4}{*}{$\begin{array}{l}\text { Behavior towards } \\
\text { Muhammadiyah } \\
\text { Fatwas }\end{array}$} & Smoking law for informants & Makruh \\
\hline & Knowledge of fatwa & Know \\
\hline & Behavior regarding fatwas & Indifferent \\
\hline & $\begin{array}{l}\text { Continuation of smoking behavior after } \\
\text { knowing the fatwa }\end{array}$ & Quit smoking \\
\hline \multirow[t]{5}{*}{$\begin{array}{l}\text { Strategies } \\
\text { for Quitting } \\
\text { Smoking }\end{array}$} & The desire to quit smoking & $\begin{array}{l}\text { Desiring to quit (desiring to live healthy, being } \\
\text { aware of the dangers of smoking, beginning } \\
\text { to feel the negative effects of smoking, having } \\
\text { family encouragement, concerning economic } \\
\text { and religious reasons) } \\
\text { Reducing smoking intensity }\end{array}$ \\
\hline & Efforts made to quit smoking & Social environment \\
\hline & Cause of failed attempts & $\begin{array}{l}\text { Psychological problems (stress and anxiety, no } \\
\text { activity, dependence on cigarettes) }\end{array}$ \\
\hline & Trouble trying to quit smoking & Determining and reducing the intensity \\
\hline & Strategies for quitting smoking & Positive activities \\
\hline
\end{tabular}

The results showed that most informants felt normal or did not feel any complaints (33.61\%) when they did not smoke. However, the psychological benefits (53.78\%) obtained directly by the informants made them maintain their smoking behavior. These advantages are reducing stress, reducing anxiety, increasing concentration, creativity, and self-confidence. Other advantages include strengthening the bonds of friendship and breaking the ice when chatting with friends. 
The informants still smoke even though they know the dangers of smoking, especially physically (63.03\%), such as cancer, heart disease, respiratory problems, and others, which usually appear in the long term.

According to (Baumeister, 2017), when making choices, it is common for the human mind to be more inclined towards choices that have immediate results rather than delayed results. It is called temporal discounting (Loewenstein in (Baumeister, 2017). The human mind tends to choose a definite outcome rather than a possible outcome. Furthermore, it is elucidated that the human mind cannot process probabilistic statistical thinking easily, therefore it chooses to think about it. Likewise, when someone chooses to keep their smoking behavior, the benefits of smoking can be felt directly by smokers, mainly in the form of enjoyment and satisfaction that is obtained immediately after smokers start smoking cigarettes. On the other hand, the disadvantages of smoking, such as lung cancer, usually appear after years of smoking. From this explanation, it can be said that the benefits or benefits of smoking are definitely felt by smokers, while the danger of suffering from lung cancer due to smoking behavior is a possible impact.

Most of the informants (63.03\%) knew that the Tarjih Council and the Muhammadiyah Central Leadership Tajdid issued a Fatwa stating that smoking is haram. However, because the informants considered the Fatwa only binding people who were members of the Muhammadiyah organization, they chose to be indifferent $(44.54 \%)$ because they felt they were not part of the organization. If religion prohibits smoking, some informants said that they will still smoke (47.06\%), but more said they will quit smoking (52.94\%). The reason the informants continued to smoke was that according to them, smoking is their right and it does not harm other people (46.43\%). Indeed, choosing to smoke or not is the right of all individuals, but it should be noted that smoking does not only harm oneself but also harms others, i.e., passive smoking. For passive smokers, exposure to cigarette smoke can cause hypertension (Janah \& Martini, 2017), heart disease, disrupt pregnancy and the fetus (Nurjanah et al., 2014), and cancer (Abrams, 2014). Another reason is that the prohibition is less strict, i.e., if smoking is prohibited, cigarettes should not be sold in various places. The informants have experienced addiction so it will be difficult not to smoke if the prohibition is not firm. (Lloyd et al., 1998) revealed that excessive emphasis on the addictive nature of cigarettes actually makes it a rationalization for adolescent and adult smokers to continue their smoking behavior. Active smokers reported that they are addicted to tobacco. Even inactive smokers (sometimes) expect to become addicted. Apart from their relatively low consumption (light and moderate smokers), smoking addiction is used to explain their smoking behavior. Regarding the less strict prohibition, in fact, it is not easy to make a firm policy that prohibits the sale and consumption of cigarettes. It is because of the importance of tobacco companies for this country. It is stated that $90 \%$ of excise revenue comes from the Tobacco Products Industry (Sasongko, 2018). Furthermore, prohibiting people from selling or consuming cigarettes is said to only benefit some parties, especially those who do not smoke. For smokers, the prohibition is considered to disrespect individual freedom and reduce their welfare (Grill \& Voigt, 2016).

Most of the informants had the desire to quit smoking. It is because they were aware of the dangers of smoking and want to live a healthy life (24.10\%). Informants began to feel the negative effects of smoking on their bodies. Another reason is because of the encouragement from family, religion prohibits, and economic reasons. Efforts that have been made by the informants to quit smoking are by reducing smoking intensity $(65.06 \%)$ or replacing cigarettes with snacks. However, these efforts often failed because the informants' social environment generally was also smokers (40.96\%). Informants had difficulty resisting the urge to smoke when they are stressed, do not have any activities, see other people smoking, or are offered cigarettes by friends. Lloyd et 
al. (1998) explained that in designing interventions, it is necessary to realize that smoking behavior by smokers has a definite positive effect. They also noted that health education programs should not make excuses to deny smokers' subjective experiences but seek to promote alternative ways of having the same effect on smokers. The positive effect of smokers in this study is that smoking can reduce stress and relieve fatigue when not doing any activity.

\section{CONCLUSION}

Most of the UMS smokers knew about cigarettes for the first time from their schoolmates, when they were in junior high school. Until now, these students have become active smokers with light and moderate intensity. Most of these students lived in a boarding house where they spend a lot of time with their friends. The factors that influenced students to try cigarettes are internal and external. Internal factors included the need for enjoyment, the need for existence, the need to be accepted by the social environment, and the need for stress coping. External factors consisted of the social environment and family environment. The reason UMS students kept their smoking behavior was that they obtained direct benefits from smoking, namely psychological benefits and social benefits. Psychological benefits included reducing stress, reducing anxiety, increasing concentration, creativity, and self-confidence. Meanwhile, the social benefits were to strengthen friendship ties and break the ice when talking with friends. UMS student active smokers were indifferent about the Fatwa issued by the Tarjih and Tajdid Council the Muhammadiyah Central Leadership, which states that smoking is haram. It was because UMS active smoking students considered the fatwa to only bind people belonging to the Muhammadiyah organization, while they felt they are not part of the Muhammadiyah organization. Most of UMS active smoking students had the desire to quit smoking but have not found an effective strategy to stop their smoking behavior.

The results of this study can be used as reference material to explain the dynamics of smoking behavior in students. This study described the smoking behavior of Muslim male students in general so that the next researcher conducts in-depth interviews so that more detailed information is obtained about smoking behavior in students who have other criteria, for example, female students, non-Muslim students, etc. Further researchers can also design a psychological intervention program that refers to the results of this study so that it can be useful for reducing the intensity of smoking behavior in students. It is also recommended that the University establish stricter smoking restrictions and ensure that everyone complies with these rules.

\section{REFERENCES}

Abdulla, A. T. B. (2020). Fatwa PP Muhammadiyah: Rokok elektrik hukumnya haram sebagaimana rokokkonvensional, ini alasannya. Tribunnews.com. Retrieved from https://www.tribunnews. $\mathrm{com} /$ nasional/2020/01/24/fatwa-pp-muhammadiyah-rokok-elektrik-hukumnya-haramsebagaimana-rokok-konvensional-ini-alasannya\#:- :text=Larangan tersebut tertuang dalam Fatwa,haram sebagaimana haramnya rokok konvensional.

Abrams, D. B. (2014). The health consequences of smoking-50 years of progress ( $A$ report of the surgeon general). Charleston SC. Retrieved from https://aahb.org/Resources/Pictures/ Meetings/2014-Charleston/PPT Presentations/Sunday Welcome/Abrams.AAHB.3.13. v1.o.pdf 
Ambarwati, Khoirotul, A., Kurniawati, F., K, T. D., \& Darojah, S. (2014). Media leaflet, video dan pengetahuan siswa sd tentang bahaya merokok (Studi pada siswa SDN 78 Sabrang Lor Mojosongo Surakarta). Jurnal Kesehatan Masyarakat, 10(1), 7-13. Retrieved from https:// journal.unnes.ac.id/nju/index.php/kemas/article/view/3064

Baumeister, R. F. (2017). Addiction, cigarette smoking, and voluntary control of action: Do cigarette smokers lose their free will? Addictive Behaviors Reports, 5, 67-84. https://doi. org/10.1016/j.abrep.2017.01.003

Grill, K., \& Voigt, K. (2016). The case for banning cigarettes. Journal of Medical Ethics, 42(5), 293-301. https://doi.org/10.1136/medethics-2015-102682

Hossain, S., Hossain, S., Ahmed, F., Islam, R., Sikder, T., \& Rahman, A. (2017). Prevalence tobacco smoking and factors associated with the initiation of smoking among university students in Dhaka, Bangladesh. Central Asian Journal of Global Health, 6(1). https://doi.org/10.5195/ CAJGH.2017.244

Janah, M., \& Martini, S. (2017). Hubungan antara paparan asap rokok dengan kejadian prehipertensi relationship between secondhand smoke and prehypertension. Jurnal Manajemen Kesehatan Yayasan RS.Dr. Soetomo, 3(2), 131. https://doi.org/10.29241/jmk.v3i1.75

Komasari, D., \& Helmi, A. F. (2011). Faktor-faktor penyebab merokok pada remaja. Jurnal Psikologi, 27(1), 37-47. Retrieved from https://scholar.google.com/scholar?q=Faktor-fakt or+penyebab+merokok+pada+remaja\&hl=id\&as_sdt $=0,5$

kompas.com. (2018). Penerimaan cukai tembakau terus meningkat. Kompas.com. Retrieved from https://nasional.kompas.com/read/2018/03/20/23224701/penerimaan-cukai-tembakauterus-meningkat

Krishna, A. S. S., Sari, M., \& Rofaida, R. (2007). Analisis tingkat literasi keuangan di kalangan mahasiswa dan faktor-faktor yang mempengaruhinya. Survey pada mahasiswa universitas pendidikan Indonesia (Financial literacy level analysis among students and its affecting factors. Survey on UPI). Academia.Edu, 1-6. Retrieved from http://www.academia.edu/ download/39830776/Analisis_tingkat_literasi_keuangan_di_ka.pdf

Lloyd, B. B., Lucas, K., Holland, J., McGrellis, S., \& Arnold, S. (1998). Smoking in adolescence: Images and identities. East Sussex, UK: Psychology Press. 